\title{
The small matter of $£ 3$ : Dynamite, human folly and the Braamfontein explosion, 19 February 1896
}

\author{
Garth Ahnie*
}

\begin{abstract}
This article discusses the Braamfontein explosion of 1896 and the chain of mistakes that led up to the blast. The explosion took place on 19 February 1896, when several trucks of dynamite exploded at Johannesburg Station after being left there for three days and following a collision with a shunting train. The force of the explosion left a massive crater and practically destroyed every home and structure in the vicinity, leaving between 1500 and 3000 residents homeless. Between 80 and 100 people lost their lives but the exact number of fatalities remains unknown because many simply "disappeared". The key question here is how did the actions of those involved with the transport, delivery and sale of the dynamite lead to the explosion? The exact cause of the blast became a mystery as the Commission of Inquiry could not reach a solid conclusion. Instead it concluded that "facts and testimonies indicate the blast occurred through the negligence - jointly or severally - by the parties involved ...". This article dissects this negligence and in so doing sheds new light on the causes of the explosion and the dispute over the $£ 3$ that set off a domino effect.
\end{abstract}

Keywords: Braamfontein; explosion; Nederlandsche-Zuid-Afrikaansche Spoorweg Maatschappij; Zuid-Afrikaansche Maatschappij van Ontplofbare Stoffen; concession system; Edouard Lippert; South African Republic.

\section{Opsomming}

Hierdie artikel bespreek die Braamfontein-ontploffing van 1896 en die reeks foute wat tot die ontploffing gelei het. Die ontploffing het op 19 Februarie 1896 plaasgevind toe verskeie waens gevul met dinamiet by die Johannesburgse stasie ontplof het weens 'n botsing met 'n trein. Dit was nadat hulle drie dae in the son gestaan het. Die krag van die ontploffing het 'n massiewe gat gelaat en elke huis en struktuur in die omgewing vernietig. Tussen 1500 en 3000 mense is haweloos gelaat en tussen 80 en 100 het hul lewens verloor, maar die presiese getal bly onbepaald, omdat hulle baie eenvoudig "verdwyn" het. Die sleutelvraag is hoe die optrede van diegene wat betrokke was by die vervoer, lewering en verkoop van die dinamiet tot die ontploffing gelei het. Die presies oorsaak van die ontploffing bly 'n raaisel omdat die Kommissie van Ondersoek tot geen gevolgtrekking kon kom nie. Die kommissie het bepaal dat die "feite en getuienisse aandui dat die ontploffing plaasgevind het deur die nalatigheid -gesamentlik of afsonderlik - van die betrokke partye ...". Die artikel ontleed hierdie nalatigheid ten einde

Garth Ahnie is a lecturer in the Department of History, University of South Africa. He is currently conducting a biographical study of Sonny Leon.

How to cite this article: G. Ahnie, "The small matter of $£ 3$ : Dynamite, human folly and the Braamfontein explosion, 19 February 1896", Historia, 64, 1, May 2019, pp 23-41. 
sodoende nuwe lig op die oorsake van die ontploffing werp, veral die dispuut oor $€ 3$ wat 'n domino-effek gehad het.

Sleutelwoorde: Braamfontein; ontploffing; Nederlandsche-Zuid-Afrikaansche Spoorweg Maatschappij; Zuid-Afrikaansche Maatschappij van Ontplofbare Stoffen; konsessies; Edouard Lippert; Suid-Afrikaanse Republiek.

On 16 February 1896, a containment of blasting gelatine was delivered to Johannesburg Station, and remained on one of the station sidings for most of the following three and a half days. On the third day, February 19, following a collision with a shunting train, the explosives detonated, causing severe damage and loss of life. The blast took place in the heart of the poorer districts of early Johannesburg - at the time, a cauldron of social, industrial and political turmoil. ${ }^{1}$ What makes the explosion fascinating is not only its unique collective setting, but the fact that a direct cause could not be found despite the investigation that followed and the incident remained shrouded in mystery. This article intends to further the discussion of the explosion and in so doing, proposes a more direct cause of the disaster.

\section{Literature on the Braamfontein explosion}

Associated literature informs us that at about 15:00 on 19 February 1896, in the railway yard of the Nederlandsche-Zuid-Afrikaansche Spoorweg Maatschappij (hereafter the Railway Company), a train of ten trucks loaded with dynamite ignited and exploded. ${ }^{2}$ The yard was in the vicinity of Braamfontein Station, at the time known as Johannesburg Railway Station and the train in question was stationed on one of the railway sidings. The explosion occurred after the dynamite trucks had been left on the siding for three days in the summer heat of February. On the third day, according to various sources, the explosion was either caused by a shunting train that was moving the trucks to a siding, when the contact set off the consignment of "sun damaged dynamite"; or, alternatively, that another set of trucks was being moved by the shunting train, and in error it crashed into the dynamite trucks, causing the explosion. ${ }^{3}$ The force of the explosion left a massive crater and destroyed buildings in

1. J.J. Fourie, "Die Dinamietontploffing te Braamfontein op 19 Februarie 1896", Historia, 31, 2 (1986), pp 17-25; C. van Onselen: New Babylon, New Nineveh: Everyday Life on the Witwatersrand, 1886-1914 (Jonathan Ball, Jeppestown, 2012), p 2; A.P. Cartwright, The Dynamite Company: The Story of African Explosives and Chemical Industries Limited, (Purnell, London, 1964), p 71.

2. University of the Witwatersrand (hereafter Wits), Historical Papers Research Archive (hereafter HPRA), A3353f, J. de Veer, "Autobiography", Excerpt J.G. Blumberg, "The Great Dynamite Explosion”, Fairmount School, Johannesburg, p 5; J. Hyslop, "A Ragged Trousered Philanthropist and the Empire: Robert Tressell in South Africa", History Workshop Journal, 51 (2001), pp 64-86.

3. Cartwright, The Dynamite Company, p 72; H.A. Chilvers, Out of the Crucible (Cassell, London, 1931), p 128; J. Davenport, "The Great Dynamite Explosion that Devastated a Fledgling Joburg", available online at Creamer Media's Mining Weekly, 
the vicinity, leaving between 1500 and 3000 local people homeless. ${ }^{4}$ The exact number of those killed by the blast was unknown because many were simply blown to pieces or "disappeared". It is understood that most of the victims were women and children because most of the men were at their place of work. ${ }^{5}$

The injured were cared for across the mining town. Hospitals overflowed and the Wanderers Sports Grounds were used as an infirmary, while the yard of the Agricultural Show was organised to shelter the homeless. ${ }^{6}$ President Paul Kruger wept, dignitaries sent condolences, a relief fund was set up and inquiries were launched to find out what had caused the disaster. ${ }^{7}$ The question to be asked was: What really caused the explosion? The most commonly held belief was that there had been a collision with the shunting locomotive, and that this, in collaboration with the intensity of the three-day heat, was the cause. ${ }^{8}$ However, when considering the chain of events that preceded the crash, it becomes apparent that there might be more to the origins of this disaster than initially thought. Furthermore, the explosives on the train had come from the Zuid-Afrikaansche Maatschappij van Ontplofbare Stoffen (hereafter the Dynamite Company), and were in fact cases of blasting gelatine and not regular dynamite. ${ }^{9}$ This form of explosive was and is, in terms of explosives, considered one of the safest to transport, and required detonators to be set off, which raises further intriguing questions about the causes of the blast. ${ }^{10}$

In Anna Smith's Pictorial History of Johannesburg, there is a notable caption which attempts (very briefly) to explain the causes of the Braamfontein explosion of 1896. It reads: "Because of some complications due to concessions and political undercurrents, some trucks of dynamite had been left in the open under a blazing sun for three days." 11 Smith surmises that the time spent in the blazing sun was the major factor in causing the blast, however what does she imply by the ambient "concessions and political undercurrents"? What Smith referred to is the South African Republic's (the Transvaal's) economic programme of issuing concessions for the supply of

http://www.miningweekly.com/article/the-dynamite-explosion-that-devastated-afledgling-joburg-2015-01-23 Accessed 11 October 2016.

4. Wits, HPRA, A3353f, De Veer, Autobiography, Blumberg, "The Great Dynamite Explosion", p 7; "Frightful Catastrophe at Johannesburg", The Cape Times, 21 February 1896, p 5; T. Gutsche, A Very Smart Medal: The Story of the Witwatersrand Agricultural Society (Howard Timmins, Cape Town, 1970), pp 48-49.

5. $\quad$ Cartwright, The Dynamite Company, p 71.

6 Wits, HPRA, A3353f, De Veer, Autobiography, Blumberg, "The Great Dynamite Explosion", p 7; G.A. Leyds: A History of Johannesburg: The Early Years (Nasionale Boekhandel, Cape Town, 1964), p 243.

7. R. Crisp, The Outlanders: The Men Who Made Johannesburg (Peter Davies, London, 1964), pp 308-309.

8. A.H. Smith (ed.), Pictorial History of Johannesburg (Juta \& Company, Cape Town, 1956), p 47; Wits, HPRA, A3353f, De Veer, Autobiography, Blumberg, "The Great Dynamite Explosion", pp 5-7; Cartwright: The Dynamite Company, p 128.

9. $\quad$ Cartwright, The Dynamite Company, $\mathrm{p} 71$.

10. K. Fant, Alfred Nobel: A Biography (Arcade Publishing, New York, 2006), pp 109-110.

11. Smith (ed.), Pictorial History of Johannesburg, p 47. 
certain commodities. This was a controversial system whereby individuals or companies could effectively gain the monopoly to provide a service or to manufacture a product for the Kruger government. Two of the most influential and contentious concessions were that of dynamite and railways, run respectively by the Dynamite Company and the Railway Company.

A contrasting theory can be found in Hedley Chilvers's 1929 book about the early days of the Witwatersrand, in which the author maintains that the infamous Jameson Raid was indirectly accountable for the blast. He claims that the raid had created a situation that meant the dynamite had to shunted to a station siding as a temporary measure. ${ }^{12}$ Chilvers mentions that William Hosken, an uitlander and businessman on the Rand, who was a representative of the dynamite giant, Nobel, was an ardent opponent of the dynamite concession. Although he was on the board of the Dynamite Company, Hosken's feelings towards the dynamite concession were very negative and he eventually joined the infamous Reform Committee that was held accountable for the failed Jameson Raid of 1895/1896. Before the events of the raid, the Dynamite Company had been using dynamite magazines belonging to Hosken; following the raid, relations between him and the Dynamite Company were severed and the use of the magazines denied. The company had other magazines but Chilvers implies that this loss of storage space created a situation whereby the dynamite that arrived from the factory at Leeuwfontein, Pretoria, had no place to go because the company's magazines were full at the time. ${ }^{13}$ He argues that this meant the trucks of explosives had to be placed on the siding in the sun for three days. Here the contents might well have degraded to a volatile point and subsequently exploded.

However, by consulting the notes on the Commission of Inquiry that followed the disaster, it becomes clear that the reasons for the explosion may have been far more simplistic and avoidable than a link to the Jameson Raid. While Chilvers's argument makes some sense, it is shown through the testimonies of the management of both the Railway Company and the office of the Dynamite Company's selling agent, Edouard Lippert, that this was not the first delay in the delivery of dynamite. There is evidence that there had been miscommunication and/or quarrels between the two offices prior to the Jameson Raid. ${ }^{14}$ Therefore trucks of dynamite standing at railway stations for any amount of time was by no means new. Although the loss of the use of Hosken's magazines would have caused some logistical issues for Lippert, the fact that his office insisted that the dynamite be delivered after the initial delay of delivery on 17 February, implies that they indeed wanted the dynamite and had space for it. ${ }^{15}$ However Lippert's office was not beyond lying or manipulation, and could have made these claims to save face, as was the case with one of its employees who was accused

12. Chilvers, Out of the Crucible, pp 127-128.

13. Chilvers, Out of the Crucible, p 128.

14. National Archives of South Africa, Pretoria (hereafter NASA), Transvaal Archives (hereafter TAB): ZAR 107, Notulen van de Commissie van Onderzoek in Zake de Dynamiet-Ontploffing te Johannesburg, 12 March 1896, pp 22-23; “The Dynamite Enquiry", The Star, 12 March 1896, p 5.

15. NASA, TAB: ZAR 107, Notulen van de Commissie van Onderzoek, 5 March 1896, p 12. 
of bribery (discussed below). ${ }^{16}$ It is also possible that on 17 and 18 of February 1896, dynamite was distributed from the magazines to clients and thus space was surreptitiously made available.

In a different account, Robert Crisp discusses a similar incident, although very briefly. He states that there was an argument between the railway yard foreman and the dynamite seller's agent, who informed the foreman that the dynamite would have to stay on the train because there was no space in the magazines. The representative further said that as they were delivering dynamite frequently, space would soon be made available. ${ }^{17}$ There is no other mention of this discussion, nor does it feature in the notes of the Commission of Inquiry.

The opinions expressed by A.P. Cartwright are also interesting. He notes the level of carelessness and even recklessness when it came to the conduct involving explosives and how, in his view, an accident was bound to occur. ${ }^{18}$ Similarly the Transvaal government's mining engineer, J. Klimke, was convinced that most of the accidents on the mines were due to "negligence, incompetence and recklessness in the use [or handling] of dynamite". Following his own investigations, he discovered that accidental explosions were the main cause of death and injury on the gold mines, and were caused by misfires and dynamite being left lying around. ${ }^{19}$

While Smith, Chilvers, Cartwright and Crisp discuss the conditions that might perhaps have led to the explosion very briefly and often superficially, only one academic article deals with the explosion more thoroughly. This article is by J. J. Fourie and was published in 1986. Fourie goes further than most mentions of the blast and provides a concise narrative of the ambient conditions. He discusses the fault of the companies involved and mentions the role played by a "quarrel over $£ 3$ ". He goes on to deal with the setting up of the Commission of Inquiry and its failure to find a definitive cause of the explosion, thus indirectly blaming the negligence of the Railway Company, the Dynamite Company and the Railway Order Service. However, Fourie does not elaborate on this negligence. He merely summarises the proceedings and conclusions of the commission. ${ }^{20}$ Curiously, he glosses over the matter of the $£ 3$.

\section{The small matter of $€ 3$}

The dynamite arrived on the evening of 16 February 1896, a Sunday, and would not be moved until the following day. ${ }^{21}$ On Monday morning (17 February) the Railway

16. NASA, TAB: ZAR 107, Notulen van de Commissie van Onderzoek, 4 \& 5 March 1896, pp 2-3, 12 .

17. Crisp, The Outlanders, $\mathrm{p} 304$.

18. Cartwright, The Dynamite Company, pp 73-74.

19. E.N. Katz, "Revisiting the Origins of the Industrial Colour Bar in the Witwatersrand Gold Mining Industry, 1891-1899”, Journal of Southern African Studies, 25, 1, 1999, p 84.

20. Fourie, "Die Dinamietontploffing te Braamfontein", pp 17-25.

21. NASA, TAB: ZAR 107, Notulen van de Commissie van Onderzoek, 12 March 1896, pp $22-23$. 
Order Service received an order from the chief of the Railway Company barracks, to collect and deliver the dynamite to the magazines of Edouard Lippert. The magazines usually received dynamite on a Monday morning from 09:45, with the average amount being around 1600 cases, and the rest being delivered on the Tuesday. Unloading the dynamite began at 10:05 and as usual, lunch was taken from 13:00 to 14:00, with work being resumed at 14:45 until 17:00. At night, the magazines were not supervised by anyone, but were securely locked and the keys were kept in a safe at the Order Service office. ${ }^{22}$

The Order Service sent five wagons and their loading master, known as Clemm, arrived at 09:35. The labourers who had to unload the explosives arrived at 10:00, at which point the work commenced, and eventually the wagons could make their first trips to the magazines. At about 11:30, Clemm returned alone to the Order Service's offices and reported that there was no one at the magazines to receive the dynamite. The head of staff instructed him to return to the magazines and to wait for someone who could take delivery of the explosive. However, at 13:00, Clemm returned again and reported that there was still no one present and that he had already taken the dynamite back to the trucks. ${ }^{23}$ Apparently Clemm re-loaded the dynamite onto the train himself without the help of an official from the Railway Company. $^{24}$ On Tuesday the Order Service was yet again contacted by the stationmaster of the Railway Company barracks, who requested that wagons be sent to collect the dynamite. No wagons were sent, because at that point, the Order Service was involved in strained deliberations with Lippert's office over a payment of $£ 3 .^{25}$

The previous afternoon, Edward Jacobs, director of the Railway Order Service, paid a visit to the administration of the railway barracks and inquired about the procedure regarding the return and subsequent delay of the dynamite delivery, specifically who had to pay for the interruption. He was informed that the consignee normally paid - the consignee being the person responsible for the receipt of a shipment. In this case Jacobs saw Lippert as the consignee, and the following morning went to his office to find out what he planned to do. He arrived at around 0:900 and there he found William Langley, a magazine caretaker for Lippert. Jacobs inquired about who would pay for the delay. Langley replied that they would not pay for a service that had not been rendered. Jacobs then told him that it would be best if Lippert himself dealt directly with the Railway Company, and meanwhile Jacobs refused to send any wagons until the matter was resolved. According to the rules, the Railway Company was responsible for payment, however when goods were ordered,

22. NASA, TAB: ZAR 107, Notulen van de Commissie van Onderzoek, 13 March 1896, p 25.

23. NASA, TAB: ZAR 107, Notulen van de Commissie van Onderzoek, 12 March 1896; also 4 and 5 March 1896, pp, 2-3, 12, 22-23; "After the Explosion", The Standard and Diggers News, 13 March 1896, pp 4-5.

24. NASA, TAB: ZAR 107, Notulen van de Commissie van Onderzoek, 4 March 1896, pp 23; "After the Explosion", The Standard and Diggers News, 13 March 1896, pp 4-5; "The Dynamite Enquiry”, The Star, 12 March 1896, p 4.

25. NASA, TAB: ZAR 107, Notulen van de Commissie van Onderzoek, 12 March 1896, pp 22-23. 
not received and had to be re-ordered then the consignee had to pay, "immediately and directly" to the Order Service. The exact contract further stated that this only applied with a certain tonnage, within a certain radius, as applied with this particular matter. The difference of the payment in this case was $£ 3.26$

William Langley, Lippert's magazine caretaker, told a different story. According to him, he and Alexander Powell, an assistant caretaker, were at the magazines from 10:00 until after 12 noon on Monday the 17 th, at which time they returned to Lippert's office in the city. They went back to the magazines at around 14:20 (this was supported by Powell's testimony) and there was still no sign of the wagons. They remained there until 17:00 and then returned to the office. ${ }^{27}$ On the Tuesday when Jacobs visited their workplace and queried about their absence at the magazines, Langley replied that no wagons had arrived. Jacobs explained that the wagons were sent at around 09:00 to which Langley quipped that then it was impossible that the wagons had not arrived yet - if they had left so early the previous day. After Jacobs left the office, Langley went to see Arthur Rutherford, the senior magazine caretaker for Lippert and the head of the office, who told him to return immediately to the magazines, but first to telephone the Order Service. Langley did so and asked if the dynamite could be re-delivered that day. The reply, oddly enough, was "yes, certainly", but no dynamite was sent. Langley and Powell waited at the magazine from $14: 15$ to $16: 45$, before returning to the office. ${ }^{28}$ This can be seen as a questionable move on the part of the Order Service.

There is a varying degree of conflicting information with regard to the delivery (or rather lack of delivery), of the dynamite to the magazines on the Monday and Tuesday in question. However, this does not change the overarching point, which is that there was a level of animosity between the Railway Order Service (or the Railway Company itself) and the office of Eduard Lippert. This was not the first time that there had been an issue with a dynamite delivery. There is evidence that in December 1895 Lippert refused to accept a delivery because he maintained that he had not ordered it and the shipment was thus returned. ${ }^{29}$ In another incident, Lippert filed a complaint against the Order Service, when his magazine caretakers waited most of the day for a delivery which only arrived at 15:30, an hour and a half before the magazines and offices closed. After the complaint, deliveries were made on time. ${ }^{30}$ There was another minor disagreement between Jacobs and Rutherford over the delivery schedule. Delays were occurring and Jacobs wanted prevent this by starting deliveries

26. NASA, TAB: ZAR 107, Notulen van de Commissie van Onderzoek, 12 March 1896, pp 22-23.

27. NASA, TAB: ZAR 107, Notulen van de Commissie van Onderzoek, 5 March 1896, p 12; "The Dynamite Enquiry", The Star, 5 March 1896, p 4.

28. NASA, TAB: ZAR 107, Notulen van de Commissie van Onderzoek, 5 March 1896, p 12; "After the Explosion", The Standard and Diggers News, 6 March 1896, p 5; "The Dynamite Enquiry", The Star, 5 March 1896, p 4.

29. NASA, TAB: ZAR 107, Notulen van de Commissie van Onderzoek, 12 March 1896, pp 22-23; “After the Explosion”, The Standard and Diggers News, 13 March 1896, p 5.

30. NASA, TAB: ZAR 107, Notulen van de Commissie van Onderzoek, 5 March 1896, p 12. 
at 06:00. He asked Rutherford if this would be possible but Rutherford refused saying such an early start would be "inconvenient" for him - the keys were locked in the office safe and he only arrived at the office at about 09:00.31 The junior caretakers were not allowed to collect the keys themselves - perhaps the only worthy precaution. ${ }^{32}$ Allowing deliveries to commence at 06:00 would have permitted more time for unloading at the magazines, and the dynamite would have had to remain at the station for a shorter period of time.

Another consideration is the behaviour and accusations of Langley. By 1896, William Langley had been working for Lippert for three years as a junior magazine caretaker, and had come across as a man with no small amount of wit. However, there were allegations made against him by one of the Order Service drivers, identified only as Fortuin, who said that Langley promised to pay him $£ 50$ if he would say that he witnessed the explosion. According to him, he saw Langley at the offices of Peycke \& Co., where Langley promised him the $£ 50$, but Fortuin claimed he had refused. ${ }^{33}$ However there is no record or testimony of this other than Fortuin's evidence and his identification of Langley during the Commission of Inquiry. Langley acknowledged that he spoke to the other drivers on the following Saturday, but that he did not know Fortuin at all and that he was never at the offices of Peycke \& Co. Why would Fortuin fabricate something like this? And yet, on the other hand, why would Langley offer to pay him to say he was at an explosion that half the city witnessed? Langley came into contact with two other drivers immediately after the explosion; both were reasonably close to the explosion and appeared to come out of the blast virtually unscathed with wagons and dynamite intact. ${ }^{34}$

Ultimately, Fortuin's testimony was not very clear and he was not specific about when he actually saw Langley - whether it was on the Monday or the Saturday. ${ }^{35}$ Still, there is a cloud of suspicion that shrouds Langley. By default, he was the most senior caretaker who was present at the magazines. The chief caretaker was absent at the time suffering from typhus fever, and it can be assumed, based on the evidence, that Langley was not as assiduous as he should have been. ${ }^{36}$ For one thing,

31. NASA, TAB: ZAR, 107, Notulen van de Commissie van Onderzoek, 12 March 1896, 5 March 1896, pp 22-23, 10-12; "After the Explosion “, The Standard and Diggers News, 13 March 1896, p 5.

32. NASA, TAB: ZAR, 107, Notulen van de Commissie van Onderzoek, 5 March 1896, pp $10-12$.

33. NASA, TAB: ZAR 107, Notulen van de Commissie van Onderzoek, 4 and 5 March 1896, pp 2-3, 12; "After the Explosion", The Standard and Diggers News, 6 March 1896, p 5; "The Diamond Enquiry", The Star, 5 March 1896, p 4.

34. NASA, TAB: ZAR, 107, Notulen van de Commissie van Onderzoek, 5 March 1896, pp 10-12; "After the Explosion", The Standard and Diggers News, 6 March 1896, p 5; "The Dynamite Enquiry", The Star, 5 March 1896, p 4.

35. NASA, TAB: ZAR 107, Notulen van de Commissie van Onderzoek, 4 and 5 March 1896, pp 2-3, 12; “After the Explosion”, The Standard and Diggers News, 6 March 1896, p 5; "The Dynamite Enquiry", The Star, 5 March 1896, p 4.

36. NASA, TAB: ZAR 107, Notulen van de Commissie van Onderzoek, 5 March 1896; and 13 March 1896, pp 12, 25. 
where was he during the dynamite delivery? Yet, whether or not Langley was present at the magazines, Clemm who was tasked with delivering the dynamite should have shown more patience in waiting for someone to receive it. Clemm also showed a lack of concern when he re-packed the dynamite himself, without the presence of a railway official. It is clear that employees from both the Railway Order Service and the office of Lippert had acted negligently with regard to their respective tasks. Moreover, the management of both offices had neglected their responsibilities.

By Wednesday morning negotiations, or rather debates about the $€ 3$ still persisted. Jacobus Pfennig, the clerk responsible for the Railway Company's barracks, was sent to Lippert to once again inquire about the payment, and the dynamite agent's office again refused to comply. Pfennig threatened to send the dynamite back to Pretoria and Rutherford retorted that he did not care what happened to the dynamite. ${ }^{37}$ It was Corneille Plate, an official at the Railway Company, who finally broke the deadlock, and urged the Order Service to deliver the dynamite and to forget about the $€ 3$, which would be paid by the Railway Company. ${ }^{38}$ Initially, Plate was unsure who had to pay the $£ 3$ for the delay, but under the circumstances he came to the decision that the dynamite should be delivered to Lippert and the Railway Company should pay the Order Service. ${ }^{39}$ Clemm and his men returned to the siding to unload the dynamite onto the mule wagons and commence delivery again. ${ }^{40}$

\section{The shunting accident}

Machinist, Jacob Bloom had been a locomotive driver with the Railway Company for three years by 1896, and had focused primarily on shunting work. Shunting is the task of pushing or pulling a train or part of a train, from the main track onto a siding or alternative track, using a locomotive. Around the same time that Clemm was busy unpacking of the dynamite, Bloom had to shunt 31 empty trucks onto one of the three sidings available at Braamfontein Station. With him was Joseph Williams, a shunter, Hendrik Vermeulen, also a shunter, Matthijs Pienaar the stoker, and Sydney Oxer, the foreman-shunter. ${ }^{41}$ Of the three sidings at the station, two were occupied with trucks. From the east, the direction which Bloom's train faced, the trucks containing the dynamite were on the right-hand siding; on the middle siding were trucks belonging

37. NASA, TAB: ZAR 107, Notulen van de Commissie van Onderzoek, 12 March 1896, pp 22-23.

38. NASA, TAB: ZAR 107, Notulen van de Commissie van Onderzoek, 13 March 1896, p 25.

39. NASA, TAB: ZAR 107, Notulen van de Commissie van Onderzoek, 20 March 1896, pp 34-35.

40. NASA, TAB: ZAR 107, Notulen van de Commissie van Onderzoek, 12 March 1896, pp 22-23; "After the Explosion", The Standard and Diggers News, 13 March 1896, p 5; "The Dynamite Enquiry", The Star, 12 March 1896, p 4.

41. NASA, TAB: ZAR 107, Notulen van de Commissie van Onderzoek, 4 March 1896; 18 March 1896, pp 4-5, 29-30; "After the Explosion", The Standard and Diggers News, 5 March 1896, p 4; "The Dynamite Enquiry", The Star, 4 March 1896, p 4 and 7 March 1896, p 5. 
to Cassel Collieries (loaded with coal and other goods). ${ }^{42}$ On the left was the open siding where the empty trucks would be shunted. In the vicinity of the station there was also a timber mill belonging to the Rand Timber Co., so the train track curved slightly around the mill's shed. This track linked with another main track which ran from central Johannesburg towards the railway yard. In front of the sidings was a road that ran across the tracks from north to south and formed a crossing there. There was routinely a policeman on duty at this crossing, and this was the case on 19 February 1896.43 At the apex of the bend around the timber mill was a large pile of wood. The empty trucks stood 50 yards from the mill at the goods station/shed where they were most likely unloaded. ${ }^{4}$

The crew operating the shunting locomotive had a mixed bag of experience and service with the Railway Company - Bloom had been with the company for three years; Williams for five years; Vermeulen, for about seven months; and Pienaar only a few weeks, starting in February. Oxer claimed to be the most experienced crew member, yet the length of his tenure is unknown. ${ }^{45}$ After the shunters connected and prepared the trucks, Bloom moved in with the locomotive and slowly began to shove the trucks, before building up more speed to push them. The normal speed for shunting was four to six miles per hour, as per the regulations of the Railway Company. Bloom testified to bringing the train to a speed of two miles per hour (equivalent to 3.2 kilometres per hour). This speed was confirmed by the others who were on the locomotive. Trains went at a slower speed around the timber mill towards the sidings because there was a slight slope down in this direction, and drivers needed to be more cautious. This was a fairly mundane and ordinary operation for the crew, who would have carried out this same routine several times a week and would have been quite efficient at it. Most of them had been involved with the shunting of the dynamite trucks just a few days previously. The locomotive used was said to be in a good condition, with an impeccable braking system. ${ }^{46}$

The ten dynamite trucks that arrived on Sunday afternoon were open-topped, covered scantily with sails; only two were covered with iron. The sidings were usually locked when trucks containing dynamite stood on them. However, it was common for the lock to either be stolen or broken, and for the last three weeks prior to the 19th,

42. NASA, TAB: ZAR 107, Notulen van de Commissie van Onderzoek, 4 March 1896, pp 45; "The Dynamite Enquiry", The Star, 7 March 1896, p 5.

43. NASA, TAB: ZAR 107, Notulen van de Commissie van Onderzoek, 4 March 1896, pp 45; and NASA, TAB: SS 5254 R1796/96, Sketch-card. See also "The Dynamite Enquiry", The Star, 4 March 1896, p 4.

44. NASA, TAB: ZAR 107, Notulen van de Commissie van Onderzoek, 4 March 1896, pp 45.

45. NASA, TAB: ZAR 107, Notulen van de Commissie van Onderzoek, pp 2, 4, 5, 29.

46. NASA, TAB: ZAR 107, Notulen van de Commissie van Onderzoek, 4 March 1896, pp 45; "After the Explosion", The Standard and Diggers News, 5 March 1896, p 4; and "The Dynamite Enquiry”, The Star, 4 March 1896, p 4. 
the lock had not been replaced. ${ }^{47}$ The siding was built at the end of 1890, crossing over into 1891, and was quickly put to use. ${ }^{48}$ Trucks that were stationed on the siding were usually secured by placing a large rock on the side facing west towards Krugersdorp. The rock would be put there so that the trucks would not roll back after this there was a "stop-block" as an added precaution to prevent the trucks from rolling away. However, if dynamite was being unloaded, the trucks would not be pushed as far as the "stop-block". Additionally, when any unloading was being carried out on the siding, another rock would be placed on the eastern side, facing Johannesburg, to make sure that the trucks would not roll backwards. ${ }^{49}$

As the foreman-shunter, Oxer was responsible for delegating work to the other shunters, in this case Williams and Vermeulen, while taking on most of the work himself. He felt this was correct because he had the most experience. He also claimed to not always follow the rules, stating that he did not understand the language (Dutch) but that nevertheless he was proficient at shunting. Included in his responsibilities was overseeing the railway turnout or switch, which is the mechanism that enables trains to be steered from one track onto another. The switch could be adjusted to lead a train onto any one of the three sidings at the station. On 19 February, Oxer instructed Williams to prepare the empty trucks for shunting, to ensure that the railway switch was correctly set, and to position himself near the front of the trucks so that he could see any possible hazards during the shunting process. It was common to have someone near the front of the train as a lookout, because the locomotive would be pushing the trucks from behind. ${ }^{50}$ At about 14:30, Williams, with Vermeulen, left the switch to prepare the trucks, and both noted that it was in order. Williams also remembered that there was a labourer cleaning the switch, or working near to it. ${ }^{51}$ Bloom also claimed he had seen the labourer cleaning the switch at about this time, while he was on his way to collect the trucks, but he did not inspect the switch because to do so was not his responsibility. He explained that he took that fact well to heart, as did most of the Railway Company employees - if it was not their responsibility they washed their hands of the matter or were oblivious to it. 52

47. NASA, TAB: ZAR 107, Notulen van de Commissie van Onderzoek, 18 March 1896, pp 29-30; “The Dynamite Enquiry”, The Star, 7 March 1896, p 5.

48. NASA, TAB: ZAR 107, Notulen van de Commissie van Onderzoek, 20 March 1896, pp 34-35.

49. NASA, TAB: ZAR 107, Notulen van de Commissie van Onderzoek, 4 March 1896, 12 March 1896, pp 4-5, 22-23; “The Dynamite Enquiry”, The Star, 7 March 1896, p 5.

50. NASA, TAB: ZAR 107, Notulen van de Commissie van Onderzoek, 18 March 1896, pp 29-30; "The Dynamite Enquiry", The Star, 7 March 1896, p 5; "After the Explosion", The Standard and Diggers News, 5 March 1896, p 4.

51. NASA, TAB: ZAR 107, Notulen van de Commissie van Onderzoek, 4 and 5 March 1896, pp 4-5, 12; "After the Explosion", The Standard and Diggers News, 5 March 1896, p 4; "The Dynamite Enquiry", The Star, 7 March 1896, p 5.

52. NASA, TAB: ZAR 107, Notulen van de Commissie van Onderzoek, 4 March 1896, pp 45; "The Dynamite Enquiry”, The Star, 7 March 1896, p 5. 
Once the crew was ready to get under way, the shunting process began. Williams gave the signal to cross over to the siding, and then climbed onto the fourth truck while it was in motion. The bend at the timber mill obscured the line of sight of those who were on the locomotive, as did the pile of timber. Going at two miles an hour, the train had just crossed over the switch when there was another signal and a shout from Williams to stop immediately. No one on board the locomotive heard the shout to stop, or saw Williams's raised hand indicating the same. Bloom, who at first could not see the switch or the crossing, eventually saw that he was on the wrong siding and immediately told the stoker to apply the brake, but it was too late and the train crashed into the dynamite trucks. Even though the brakes were applied immediately, a train does not come to a halt right away, and adding to this was the weight of the 31 trucks. The switch was set incorrectly - it led the train onto the dynamite siding instead of directing it to the empty siding, as was intended. ${ }^{53}$

The foreman of the timber mill was observing the shunters going about their business. Earlier in the day he had commented to Oxer, who was busy with the coal trucks at the time, to be careful while shunting, else he would send them all flying into the air - referring of course to the nearby dynamite trucks. On the previous day, he had also seen trucks being shunted against other trucks and this motivated his words of caution. ${ }^{54}$ The foreman could not determine how fast the train was travelling, but he did say that in his view the force was enough to overturn the trucks when they collided. He did not specify which trucks were overturned, and it is also important to mention that no one else testified to seeing any of the trucks being overturned by the impact. ${ }^{55}$ Another question that can be asked is how a train going at only two miles an hour (as the crew said) would be able to push over another train or cause it to derail. There is also the possibility that one of the trucks simply derailed and then overturned or fell over during the collision. The slope of the track should also be taken into consideration, because it would have added an extra bit of force at an angle as well as the weight of the trucks. ${ }^{56}$

\section{After the collision}

The exact events following the collision are unclear. The testimonies provided by those on the train vary, sometimes even within the evidence given by the same person. What is indeed known is that the explosion followed the collision - whether immediately, a few seconds later or after a few minutes - is uncertain. The shunting crew stated that they could not swear they had hit the dynamite trucks. They all said

53. NASA, TAB: ZAR 107, Notulen van de Commissie van Onderzoek, 4 March 1896, 18 March 1896, pp 4-5, 29-30.

54 "Dynamite Inquiry", The Cape Argus, 14 March 1896, p 5; "National Disaster", The Standard and Diggers News, 20 February 1896, p 4.

55. NASA, TAB: ZAR 107, Notulen van de Commissie van Onderzoek, 13 March 1896, p 25.

56. NASA, TAB: ZAR 107, Notulen van de Commissie van Onderzoek, 4 March 1896, 12 March 1896, 18 March 1896, pp 4-5, 22-23, 29-30. 
that they did, but that they could not swear to it without a degree of doubt. ${ }^{57}$ This might well have been for fear that they would be blamed for the disaster and in the hope that they could divert a bit of the responsibility away from themselves perhaps they argued that there was another feasible reason for the explosion, and their being on the wrong siding was just a mere coincidence.

Pienaar, the stoker, recounted that while he was applying the brakes, the explosion erupted and that he did not feel any shock but did hear the explosion. ${ }^{58}$ Pienaar, like the rest, was probably knocked unconscious by the blast. Vermeulen recalls Bloom shouting "Stop!", was aware that the stoker applied the brake, and then felt the blast, after which he lost consciousness. However, he claimed he did not hear the collision of the trucks, and could not even say whether he knew if the trucks were still moving or had come to a stop when the explosion took place. ${ }^{59}$ Oxer too, said that he did not feel any collision, but his timing of the explosion varies from the others. He initially said that the explosion occurred one minute after the collision (which he claimed he did not feel) and later described it as one and a half minutes after the brake had been applied. ${ }^{60}$ Bloom, in the same breath, said that the explosion followed the collision, and then immediately afterwards said that the explosion was before the shock, before contact was made with the trucks. ${ }^{61}$ What he might perhaps have meant is that the explosion followed so instantaneously that there was no time for a reaction to the crash itself.

The fact that these witnesses were unsure whether there was a collision prior to the explosion, does not negate the obvious - that the explosion followed the collision. It would be a major coincidence if the blast went off just before the collision, but one cannot follow coincidences until there is enough evidence to support them. The crew, whose testimonies are perhaps the most crucial in this paper, cannot be fully trusted with regard to the exact moment the explosion occurred. The event itself would have caused too much of an impact on both their physical and mental functioning - they would have been injured and knocked unconscious, thus clouding their memory. Adding to this unreliability is the fact that those who were on the locomotive were 31 trucks away from the epicentre of the explosion, and they were around a bend in the track with a pile of wood and a shed obscuring their view of the area. Williams, who was closer to the front of the train, fell off just as the trains

57. NASA, TAB: ZAR 107, Notulen van de Commissie van Onderzoek, 4 March 1896, pp 45; "The Dynamite Enquiry", 7 March 1896, p 5.

58. $\quad$ NASA, TAB: ZAR 107, Notulen van de Commissie van Onderzoek, 4 March 1896, pp 45; “The Dynamite Enquiry”, The Star, 7 March 1896, p 5.

59. NASA, TAB: ZAR, 107, Notulen van de Commissie van Onderzoek, 5 March 1896, p 12; "After the Explosion", The Standard and Diggers News, 5 March 1896, p 4; "The Dynamite Enquiry", The Star, 4 March 1896, p 4 and 7 March 1896, p 5.

60. NASA, TAB: ZAR 107, Notulen van de Commissie van Onderzoek, 18 March 1896, pp 29-30; "The Dynamite Enquiry", The Star, 7 March 1896, p 5.

61. NASA, TAB: ZAR 107, Notulen van de Commissie van Onderzoek, 4 March 1896, pp 45; "After the Explosion", The Standard and Diggers News, 5 March 1896, p 4. 
collided and was also knocked unconscious by the explosion or the fall; he could not give specifics about that moment of impact.

The man who was said to be cleaning the switch before the explosion, was later instructed by Williams to be on the first truck during the shunting as an additional lookout, but was never seen again; he was probably killed instantly by the blast. ${ }^{62}$ It should also be noted that at around this time Clemm, the man employed by the Order Service, and his workmen were busy unloading the dynamite from the trucks, and were no doubt killed instantly.

What is clear is that the switch was incorrectly set. Again the crew could not say how this might have happened. Williams and Vermeulen both claimed it was in order when they had inspected it; Oxer stated that he instructed Williams to check the switch; and Bloom and Pienaar would have had little to do with the operation of the switch on this fateful day. Oxer, Bloom and Williams all mentioned that there was a labourer who cleaned the switch about half an hour before the explosion. They do not say specifically (but merely imply) that this man may have changed the setting of the switch while he was cleaning it. However, none of them could provide anything more than conjecture - that it was possible that someone either by accident, or through ill will, could have tampered with the switch. ${ }^{63}$

Other questions have to be considered: Why was Williams not on the front of the train as he was instructed by Oxer? And secondly, why did Williams instruct the labourer to be in front? Furthermore, Oxer was adamant that from where Williams gave the signal to cross over the switch, he would have been able to see the switch very clearly and should have noticed that it was not in the correct position. ${ }^{64}$ What is confirmed here is that the contact between the shunted trucks and the dynamite trucks was an accident (and that the accident was due to negligence).

\section{Culpability}

An opinion piece in The Cape Argus, placed the blame firmly on the Railway Company, calling its conduct that of "gross carelessness and ignorance", and adding that it was "silly and grotesque, while causing a serious waste of time and power". ${ }^{65}$ Further opinions were aired on the qualifications of the railway commissioner. He was criticised heavily, saying that the only reason he had been given the job was that he knew absolutely nothing about the workings of the railway. ${ }^{66}$ It was also reported

62. NASA, TAB: ZAR 107, Notulen van de Commissie van Onderzoek, 4 March 1896, pp 45.

63. NASA, TAB: ZAR 107, Notulen van de Commissie van Onderzoek, 4 March 1896, and 18 March 1896, pp 4-5, 29-30.

64. NASA, TAB: ZAR 107, Notulen van de Commissie van Onderzoek, 18 March 1896, pp 29-30.

65. "Terrible Explosion on the Rand", The Cape Argus, 20 February 1896, p 5.

66. "Things on the Rand", The Cape Argus, 25 February 1896, p 5. 
that President Kruger's anger was initially directed at the Railway Company. ${ }^{67}$ This was the most logical explanation because the disaster had happened in the grounds of the company, and it was the incompetence of the staff that had led to the accident. There was, however, minor finger pointing between Oxer and Williams (foremanshunter and shunter respectively), as to the responsibilities and abilities of each. Oxer maintained that he had placed Williams near the front of the train and that it was thus Williams's responsibility to be on the lookout; he (Oxer) felt that he was therefore absolved of blame. Oxer claimed that had he been in front he would have spotted the error immediately. Williams, on the other hand, stated that ultimately it was Oxer's responsibility, as head shunter, to inspect and secure the switch. ${ }^{68}$

During the investigation, Friedrich Krieger, director of the dynamite factory at Leeuwfontein, explained how dynamite cases should be handled when being unloaded. He did not go into depth, but it can be assumed from his few words, that the handling of the dynamite in this incident was less than appropriate. ${ }^{69}$ In addition, it was revealed that many of the workers who offloaded the dynamite had received no training in how to handle explosives. Hendrik Dirk de Bruyn, a twenty-year-old, had been working for the Railway Company for only three months when the explosion took place. His sister told newspapers that he had little or no experience with explosives and would not have fully understood its dangers. The young man was said to be fit and strong, with an interest and experience in weightlifting, so he would definitely have been able to lift a heavy case of dynamite. However he had been at work from 06:00 on 19 February, with the explosion taking place at around 15:15 - a combination of inexperience and fatigue could therefore have played a part in alleged negligence. ${ }^{70}$

Referring to the eye witness accounts of the unloading methods employed by the railway workers, there was evidence that cases of dynamite were sometimes thrown from the train onto the wagons. The negligence of the Railway Company, in combination with its Order Service wing, thus becomes further apparent. ${ }^{11}$ Yet the Railway Company was not the only guilty party. It was alleged that the Dynamite Company was inconsistent in its regulations concerning the delivery of dynamite and the care of its product. With the understanding that dynamite is a dangerous product and a potentially volatile one, the company should have been more careful in its activities and attitudes. In the mines, accidents involving explosives occurred for the same reasons - negligence and carelessness. Many miners who used dynamite were untrained, thus who was really to blame, the miner or the officials who were responsible for training them correctly? ${ }^{72}$

67. Chilvers, Out of the Crucible, p 128.

68. NASA, TAB: ZAR 107, Notulen van de Commissie van Onderzoek, 4 March 1896, pp 45; “The Dynamite Enquiry”, The Star, 7 March 1896, p 5.

69. NASA, TAB: ZAR 107, Notulen van de Commissie van Onderzoek, 11 March 1896, pp 12-13.

70. "The Rand Catastrophe”, The Cape Times, 22 February 1896, p 5.

71. "Rand Calamity", The Cape Argus, 26 February 1896, p 5.

72. Katz, "Revisiting the Origins of the Industrial Colour Bar", p 86. 
Another act of carelessness linked to the disaster was that detonators were onboard the dynamite train, due to miscommunication. Although the proximity of the detonators alone would not have led to the explosion, having detonators stored near cases of dynamite was forbidden. ${ }^{73}$ Furthermore, insufficient caution was shown when explosives were being transported. Often wagon loads of dynamite would speed through the town, with only one driver to supervise them, and it was not uncommon to see the driver smoking a pipe! His knowledge of the dangers of dynamite must have been minimal. However, pipe smoking while offloading the dynamite in the railway yard on 19 February 1896 cannot be proven. ${ }^{74}$ Turning to the quality of the explosives, samples of blasting gelatine that were removed from the trucks prior to the explosion were tested by a notable Scottish engineer ${ }^{75}$ as well as two Transvaal chemists, and the explosives were found to be of high quality and in very good condition. Unless there was an extraordinary flaw in that particular consignment, the quality of the explosives was adjudged to be excellent. ${ }^{76}$

It cannot be denied that the final known act before the explosion was the shunting accident. Anything that happened while the dynamite was being offloaded is in the realm of pure speculation The obvious question arises: Had there not been a shunting accident would there have been an explosion? This article would say no. It would simply be a coincidence, and that was highly unlikely. The disaster was a perfect storm - everything that could have gone wrong went wrong. The dynamite was left unattended for three days, open to the elements. The delay was caused by a trivial dispute over the payment of $€ 3$ that could have been rectified easily, as was ultimately the case. Through human error the railway switch was incorrectly set and this led to the collision which was followed directly by the explosion. Thus whether or not blasting gelatine was considered safer; or that witnesses with experience claimed that cases often fell with no consequences; or even that the gelatine that survived was tested and found to be of a high quality, cannot take away the fact that the explosion followed the collision.

The Commission of Inquiry made a close study of the various facts, circumstances and testimonies and concluded that the direct cause of the explosion could not be established. However, it did specify that: "All the facts and testimonies indicate that the blast occurred through the negligence - be it jointly or severally - by the parties involved." The parties were: i) the Railway Company; ii) the Order Service; and iii) the Dynamite Company. ${ }^{77}$ In closing, the commission drew attention once

73. NASA, TAB: ZAR 107, Notulen van de Commissie van Onderzoek, 11 March 1896, pp 12-13.

74. “The Rand Catastrophe”, The Cape Times, 25 February 1896, p 5.

75. Robert Tatlock, a public analyst and gas examiner for the city of Glasgow, was on business in Johannesburg while the enquiry and was being held and was asked to examine the quality of the blasting gelatine from the consignment that exploded.

76. NASA, TAB: SS 5254 R1796/96, Report on the Condition and Quality of 120 Cases of Blasting Gelatine at No. 2 Magazine, Braamfontein; and SS 5254 R1796/96, Rapport van die Commissie tot Onderzoek der dynamiet-ontploffing, $\mathrm{p} 48$.

77. NASA, TAB, ZAR, 107, Rapport van die Commissie tot Onderzoek, 1896, p 46. 
more to the statement of the Scottish engineer and his findings that the blasting gelatine was of a good quality. It accepted this report in its entirety. It further expressed that it was impossible that the explosives detonated due entirely to the shock of the accident. Unless, that is, if there was a mistake "here or there" or a "secret flaw" that made the collision, the impact, a causative factor. Moving on, it reiterated that there were several testimonies that revealed a degree of negligence that might have led to the explosion. Nevertheless, the commission recognised that it had failed to discover the direct cause. The reckless manner in which the explosives were loaded and unloaded was another possible cause but because all the potential witnesses had "disappeared" (perished in the explosion) it was impossible to establish this. ${ }^{78}$ The commission could not confirm a direct cause due to the loss of crucial witnesses and the unreliable testimonies of those who had survived.

\section{Conclusion}

The following discussion summarises the chain of events that led to the explosion. On arrival the dynamite could not be immediately offloaded and delivered as was regulation; it was instead moved to the Braamfontein Station siding. An attempt was made to deliver the dynamite but there was no one to receive it at the magazines. Further delivery was strained and halted by conflict over the payment of $€ 3$. The dynamite remained in the trucks for three and a half days during February, which is known for its high temperatures, and it was said to be a particularly hot week. Could the constant transport back and forth also have led to the degradation of the explosives? When the dynamite was repacked after the failed delivery, was it packed correctly and safely? The presence of detonators on the train, although on a separate truck, complicates matters as well, especially when one considers the repacking and whether or not the dynamite and the detonators landed up on the same truck. The general routine of packing dynamite was later criticised for being reckless and dangerous. Eventually the dispute over the payment of the $£ 3$ was resolved and the offloading and delivery of the dynamite began. The railway switch that was set incorrectly led to the collision (which occurred during the offloading of the dynamite), and was ultimately the final nail in the coffin because directly after this, the explosion occurred. There were also discrepancies about the possible speed of the shunting train.

In the aftermath of the blast, various explosive articles were found, such as unexploded dynamite, detonators and fuses. One article of dynamite was noted to be oozing gelatine. There were also several claims that the dynamite was of a poor quality. However, during the investigation, based on the opinion of experts in the field, the blasting gelatine was found to be of a sound quality. It is unlikely that there was a freak flaw in the dynamite that exploded and in any case this could not be identified afterwards.

78. NASA, TAB, ZAR, 107, Rapport van die Commissie tot Onderzoek, 1896, p 48. 
The unfortunate series of events that led to the explosion, could have been avoided, it was just a simple case of being in the wrong place at the wrong time - a perfect storm. Fourie points out that the Commission of Inquiry found no direct cause, but he maintains that the debate over the $£ 3$ was a leading cause of the explosion. ${ }^{79}$

This article argues that the small matter of the $£ 3$ may well have been the initial spark that set off the unfortunate chain of events. Ultimately, however, it was but one of many issues which led to the explosion. Undoubtedly it was the collision which was the direct cause of the blast. One should refer back to the findings of the Commission of Inquiry which states that there was no direct cause, but it cannot be emphasised enough that the explosion followed the collision. Human pettiness and negligence certainly played their part as well, and the commission admits this, but the investigations did not identify direct culprits. ${ }^{80}$ Whatever the reasons for the commission's conclusions, they do not take away from the fact that the matter of the $£ 3$, and the delay this caused was the first step, the trigger, for the accident and the chain of events which led to the explosion. Through their negligence, albeit indirectly, the only culprits were the employees of the Railway Company, the Dynamite Company and the Order Service.

\section{REFERENCES}

Cartwright, A.P., The Dynamite Company: The Story of African Explosives and Chemical Industries Limited (Purnell, London, 1964).

Chilvers, H.A., Out of the Crucible (Cassell, London, 1931).

Crisp, R., The Outlanders: The Men Who Made Johannesburg (Peter Davies, London, 1964).

Davenport, J., "The Great Dynamite Explosion that Devastated a Fledgling Joburg", Creamer Media's Mining Weekly, at http://www.miningweekly.com/article/thedynamite-explosion-that-devastated-a-fledgling-joburg-2015-01-23 Accessed 11 October 2016.

Fant, K., Alfred Nobel: A Biography (Arcade Publishing, New York, 2006).

Fourie, J.J., "Die Dinamietontploffing te Braamfontein op 19 Februarie 1896", Historia, 31, 2(1986).

Gutsche, T., A Very Smart Medal: The Story of the Witwatersrand Agricultural Society (Howard Timmins, Cape Town, 1970).

Hyslop, J., "A Ragged Trousered Philanthropist and the Empire: Robert Tressell in South Africa", History Workshop Journal, 51(2001).

Katz, E.N., "Revisiting the Origins of the Industrial Colour Bar in the Witwatersrand Gold Mining Industry, 1891-1899”, Journal of Southern African Studies, 25, 1 (1999).

79. Fourie, "Die Dinamietontploffing te Braamfontein", pp 19, 23.

80. NASA, TAB, ZAR, 107, Rapport van die Commissie tot Onderzoek der dynamietontploffing, 1896. 
Leyds, G.A., A History of Johannesburg: The Early Years (Nasionale Boekhandel, Cape Town, 1964).

Smith, A.H. (ed.), Pictorial History of Johannesburg (Juta \& Company, Cape Town, 1956).

Van Onselen, C., New Babylon, New Nineveh: Everyday Life on the Witwatersrand, 1886-1914 (Jonathan Ball Publishers, Jeppestown, 2012). 